\title{
Genotoxicity Studies of Titanium Dioxide Nanoparticles $\left(\mathrm{TiO}_{2} \mathrm{NPs}\right)$ in the Brain of Mice
}

\author{
Hanan R. H. Mohamed and Nahed A. Hussien \\ Zoology Department, Faculty of Science, Cairo University, Giza 12613, Egypt \\ Correspondence should be addressed to Nahed A. Hussien; nahed@sci.cu.edu.eg
}

Received 3 December 2015; Revised 19 January 2016; Accepted 4 February 2016

Academic Editor: Andrij Holian

Copyright (C) 2016 H. R. H. Mohamed and N. A. Hussien. This is an open access article distributed under the Creative Commons Attribution License, which permits unrestricted use, distribution, and reproduction in any medium, provided the original work is properly cited.

\begin{abstract}
Titanium dioxide nanoparticles $\left(\mathrm{TiO}_{2} \mathrm{NPs}\right)$ are excessively used and represent one of the top five most commonly used nanoparticles worldwide. Recently, various studies referred to their toxic potential on various organs using different treatment route. Male Swiss Webster mice were orally administrated $\mathrm{TiO}_{2} \mathrm{NPs}(500 \mathrm{mg} / \mathrm{kg}$ b.w.) daily for five consecutive days and then animals were sacrificed at $24 \mathrm{~h}, 7$ days, or 14 days after the last treatment. The present results report that exposure to $\mathrm{TiO}_{2} \mathrm{NPs}$ produces mild to moderate changes in the cytoarchitecture of brain tissue in a time dependent manner. Moreover, Comet assay revealed the apoptotic DNA fragmentation, while PCR-SSCP pattern and direct sequencing showed point mutation of Presenilin 1 gene at exon 5, gene linked to inherited forms of the Alzheimer's disease. Therefore, from these findings, the present study concluded that $\mathrm{TiO}_{2} \mathrm{NPs}_{1}$ is genotoxic and mutagenic to brain tissue which in turn might lead to Alzheimer's disease incidence.
\end{abstract}

\section{Introduction}

Nanotechnology means a new set of technologies that are used to develop nanoscale structures and devices with one dimension size $1-100 \mathrm{~nm}$ with special properties utilized in commercial applications [1]. Nanotechnology promises a great contribution to humanity, but without appropriate assessment of risks and safely, public confidence in this expanding field will diminish [2].

Concern has been raised about the effect of nanoparticles exposure on human health $[3,4]$. Titanium dioxide $\left(\mathrm{TiO}_{2}\right)$ is a widely used industrial nanomaterial that was used in various products including sunscreens, lacquers, and paints [5]. Therefore, $\mathrm{Nano}_{-} \mathrm{TiO}_{2}\left(\mathrm{TiO}_{2} \mathrm{NPs}\right)$ risk assessment should be an integral part nowadays in our modern society. Human exposure to $\mathrm{TiO}_{2} \mathrm{NPs}$ may occur during both manufacturing and use. The major routes of $\mathrm{TiO}_{2} \mathrm{NP}$ exposure that have toxicological relevance in the workplace are inhalation and dermal exposure. Oral exposure, as a nonmajor route, may occur from toothpaste, food colorants, and nutritional supplements that contain $\mathrm{TiO}_{2} \mathrm{NPs}$. In a recent study by Weir et al. [6], they found that candies, sweets, and chewing gums contained the highest amount of $\mathrm{TiO}_{2}$ in the scale of $<100 \mathrm{~nm}$.
In nanomedicine, intravenous or subcutaneous injection of $\mathrm{TiO}_{2}$ nanoparticulate carriers is a unique way to deliver $\mathrm{TiO}_{2} \mathrm{NPs}$ into the human body [7].

Evidence of $\mathrm{TiO}_{2} \mathrm{NPs}$ exposure genotoxicity has been previously researched within various studies, including micronuclei development, DNA damage, and in vitro mammalian chromosomal aberrations. Moreover, genotoxicity investigations of different nanomaterials were published in an openly available scientific literature from all biological models [8].

Because of their nanosize and unique properties, nanoparticles can enter the body and freely cross different biological barriers. Various studies have assessed that inhaled/ injected nanoparticles enter systemic circulation and migrate to different organs and tissues $[9,10]$; in turn they could accumulate and damage them, especially those sensitive to oxidative stress (OS).

Oberdorster et al. [11] and Sager et al. [12] reported that $\mathrm{TiO}_{2} \mathrm{NPs}(21 \mathrm{~nm})$ caused a higher pulmonary inflammatory response than $\mathrm{TiO}_{2}$, because $\mathrm{TiO}_{2} \mathrm{NPs}$ enter the alveolar interstitium with a much greater amount than $\mathrm{TiO}_{2}$. Another study revealed that a small fraction of pulmonary $\mathrm{TiO}_{2} \mathrm{NPs}$ were able to access the blood circulation and reach 
extrapulmonary tissues such as liver and kidneys, at 28 days after instillation [13].

The brain is another organ that could be severely affected by nanoparticle induced oxidative stress (OS) due to its high energy demands, low levels of endogenous scavengers, and high cellular concentration of OS targets. Recent experimental studies indicate that nanoparticles can cross the bloodbrain barrier [14] and enter the central nervous system of exposed animals in low numbers $[10,15]$.

Presenilin 1 (PSEN1) gene is one of four important genes that are linked to inherited forms of the Alzheimer's disease (AD). Previous studies reported that mutation of PSEN1 gene leads to alternation of the intramembranous cleavage of the $\beta$-amyloid precursor protein by $\gamma$-secretase enzyme. In turn, this altered $\beta$-amyloid precursor protein increased the production of $\mathrm{A} \beta_{42}$ that is accumulated chronically in some brain regions with very little production to fibril-rich amyloid plaques and few related neuritic and glial cytopathology; this leads to dementia. Selkoe [16] report in detail this hypothetical sequence of the pathogenetic steps of familial forms of $\mathrm{AD}$.

The present study focuses on the histological, genotoxic, and mutagenic effect of $\mathrm{TiO}_{2} \mathrm{NPs}$ on mice brain cells using histological assay, COMET assay, detection of point mutation of PSEN1 gene (AD related gene) using SSCP evaluation followed by direct sequencing for mutated samples. Additionally, the present study aimed to know if there is a relation between $\mathrm{TiO}_{2}$ NPs exposure and AD incidence.

\section{Material and Methods}

2.1. Animals. This study was performed on 12 mature male Swiss Webster mice, weighing about 25-30 g b.w. and aged 10-12 weeks. Animals were purchased from National Research Center animal house (Dokki, Giza, Egypt). Mice were housed for 7 days to be accommodated with our laboratory conditions. Food and water were presented ad libitum. Animals received care according to the criteria outlined in the "Guide for the Care and Use of Laboratory Animals."

2.2. $\mathrm{TiO}_{2} \mathrm{NPs}$ and Their Characterization. The $\mathrm{TiO}_{2} \mathrm{NPs}$ used in this study were a mixture of rutile and anatase forms purchased from Sigma Chemical Co., (St. Louis, MO, USA) in the form of odorless and white powder in the nanoscale range $<100 \mathrm{~nm}$ using Brunauer-Emmett-Teller (BET) method and $<50 \mathrm{~nm}$ using X-ray diffraction method with a purity of 99.5\% and CAS number 13463-67-7. As mentioned in our previous study [17], $\mathrm{TiO}_{2} \mathrm{NPs}$ were ultrasonicated in deionized distilled water using the biologics ultrasonic homogenizer (Model 150VT) immediately prior to characterization and administration and the $\mathrm{pH}$ value of $\mathrm{TiO}_{2} \mathrm{NPs}$ suspensions was 6.8 and characterized using $\mathrm{X}$-ray diffraction (XRD) to identify the crystal phase and the average crystallite size. Indeed, the particle size and morphology of $\mathrm{TiO}_{2} \mathrm{NPs}$ suspensions were detected using transmission electron microscopy (TEM) and the dispersion and aggregation status of these nanoparticles in water were determined by the dynamic light scattering (DLS) method using particle size distribution and zeta potential analyzer (Zeta sizer Nano ZS90, Malven Instruments, UK).

2.3. Experimental Protocols. Mice were divided into four groups, 3 mice/group: Group 1: negative control group (untreated group); Groups 2, 3, and 4: animals daily were orally administrated $\mathrm{TiO}_{2} \mathrm{NPs}$ by oral gavage $(500 \mathrm{mg} / \mathrm{kg}$ [18]) for 5 days and were sacrificed at 24 h, 7 days, and 14 days, respectively. After dissection, the brain tissues were excised for further evaluation.

2.4. Histopathological Evaluation. The brain was removed from the skull, and brain tissue portion was fixed in $10 \%$ neutral buffer formalin, washed with tap water, and dehydrated in a series of alcohols. The dehydrated tissue was cleared by using xylol and then embedded in paraffin wax at $60^{\circ} \mathrm{C}$; blocks were cut at 5 microns using a microtome. Brain sections were stained using haematoxylin and eosin [19] for the investigation of general histological changes.

\subsection{Molecular Evaluation}

2.5.1. DNA Extraction and PCR Amplification. Genomic DNA was extracted from brain tissue portion using the Genomic DNA Purification kit (Fermentas) according to the manufacturer's instructions. The quantity of DNA was estimated by absorbance reading at $260 \mathrm{~nm}$ and DNA shows more purity was estimated by ratio of absorbance reading between 260 and $280 \mathrm{~nm}$.

For polymerase chain reaction (PCR), P1 forward $5^{\prime}$ aatctacaccccattcacag- $3^{\prime}$ and reverse $5^{\prime}$-gcccccaactctcccacc- $3^{\prime}$ were used to amplify exon 5 of PSEN1 gene (231 bp) of mouse [20]. The PCR reaction mixture was set up using sterile water, $100 \mathrm{ng} / \mu \mathrm{L}$ of extracted DNA, $1 \mu \mathrm{L}$ forward/reverse primers $(20 \mathrm{pmol} / \mu \mathrm{L})$, and $10 \mu \mathrm{L} 2 \mathrm{x}$ ready to use master mix (Fermentas) in a $0.2 \mathrm{~mL}$ PCR eppendorf tube. Cycling was started in the Thermal Cycler (Programmable Thermal Cycler, PTC-100TM thermal cycler, Model 96; MJ Research, Inc., Watertown, MA, USA), with initial denaturation at $94^{\circ} \mathrm{C}$ for 3 mins, denaturation at $94^{\circ} \mathrm{C}$ for $30 \mathrm{~s}$, primer annealing at $60^{\circ} \mathrm{C}$ for $1 \mathrm{~min}$, and then primer extension at $72^{\circ} \mathrm{C}$ for $1 \mathrm{~min}$, for 35 cycles. At the end, final extension at $72^{\circ} \mathrm{C}$ for 5 mins was necessary for complete amplification. PCR products were separated and visualized by electrophoresis on a $1.5 \%$ ethidium bromide-treated agarose gel (Sigma, UK) according to the standard protocol described by Sambrook et al. [21].

2.5.2. Single-Strand Conformation Polymorphism (SSCP) Analysis and Sequencing. PCR products were denatured using TE buffer ([22]; diluted 1:10, pH 8.0). Then, five microliters of diluted solution was mixed with $5 \mu \mathrm{L}$ of denaturingloading dye (95\% formamide, $4 \mathrm{M}$ urea, $0.1 \%$ bromophenol

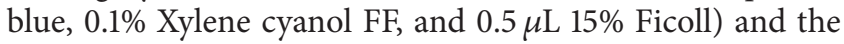
mixture was heated to $94^{\circ} \mathrm{C}$ for 5 mins; then, the mixture was chilled directly on ice for $10 \mathrm{mins}$ [23]. The denaturated PCR samples were subjected to $9 \%$ polyacrylamide gel electrophoresis (acrylamide/bisacrylamide $=49: 1, \mathrm{v} / \mathrm{v}$ ). At the end, the gel was stained in $100 \mathrm{~mL} 1 \times \mathrm{TBE}$ and $10 \mu \mathrm{L}$ ethidium 


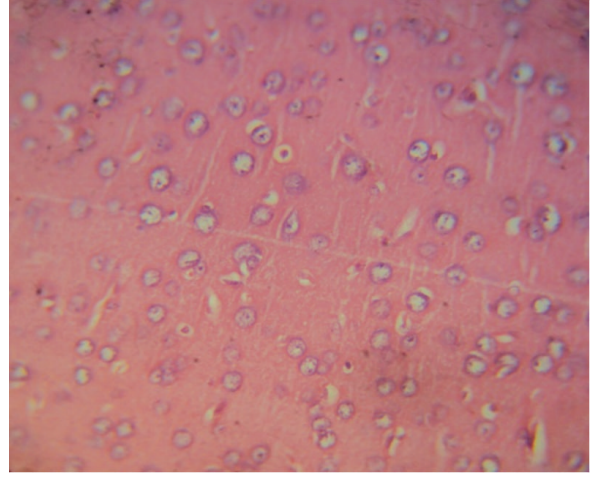

(a)

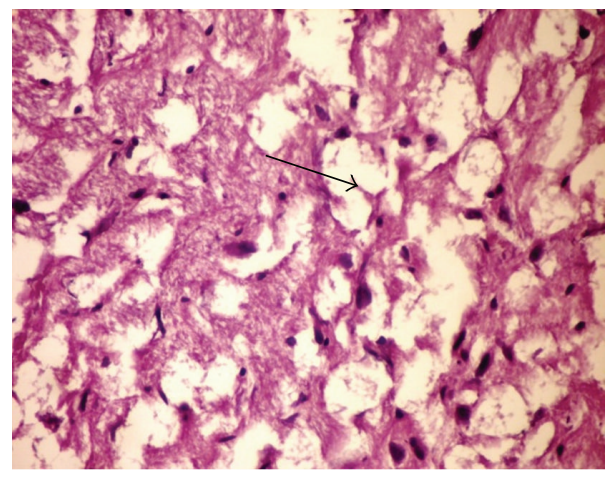

(c)

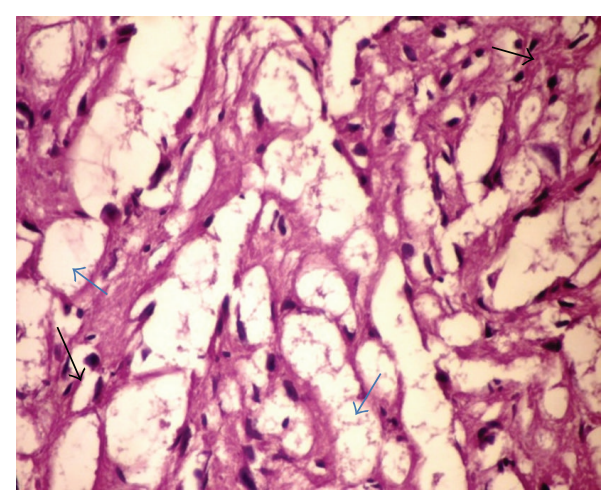

(b)

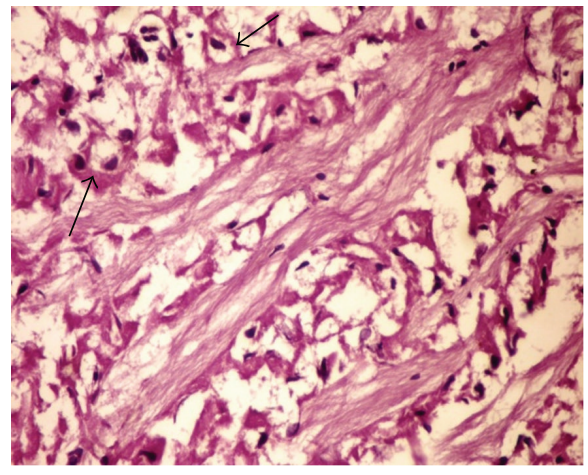

(d)

Figure 1: Photomicrograph of brain sections of different groups, in which (a) represents negative control; (b) 24 h group showing extracellular brain edema (blue arrows) and intracellular brain edema (black arrow); (c) 7-day group showing an extracellular edema (arrows); (d), 14-day group showing vacuolation (arrows), respectively. Hematoxylin and eosin staining at 400x.

bromide $(10 \mathrm{mg} / \mathrm{mL})$ and shook for 10 mins to visualize the DNA bands. The gel was placed on a UV trans-illuminator (Stratagene, USA) and pictures were taken with a Polaroid camera (Polaroid MP4 Land Camera).

Bands that abnormally shifted in the SSCP gel compared with their corresponding normal control were considered to harbor somatic mutations. The PCR products that showed mutation using SSCP were sequenced for detection of point mutation.

Amplification products were purified using the QIAquick PCR purification kit (Qiagen, GmbH, Germany). Cycle sequencing of both strands was performed using the BigDye Terminator Kit version 3.1 (Applied Biosystems, Foster City, CA) on an ABI Prism 3730 Genetic Analyzer automated sequencer. Primers for sequencing are described by Morimura et al. [24]. Sequence data was analyzed using the Sequencher 4.1 software package (Gene Codes, MI). If the DNA sequence at a particular location in the DNA differed from the corresponding normal DNA, then it was defined as a somatic mutation.

2.5.3. Comet Assay. The alkaline comet assay was performed as described in detail by Singh et al. [25]. Frosted microscopic slides were dipped into hot $1.0 \%$ normal melting point agarose and then the excess agarose was wiped from the underside of the slide. $10 \mu \mathrm{L}$ of homogenized brain tissue in cold Hank's Balanced Salt Solutions was mixed with $65 \mu \mathrm{L}$ of $0.5 \%$ low melting point agarose at $37^{\circ} \mathrm{C}$ and covered using a slide cover to spread the samples. The slides were left in lysis solution (2.5 M NaCl, $100 \mathrm{mM} \mathrm{Na}{ }_{2}$ EDTA, 10 mMTris, $\mathrm{NaOH}$ to $\mathrm{pH} 10.0,1 \%$ Triton-100, and 10\% DMSO) for 2 hours at $4^{\circ} \mathrm{C}$. The slides were dipped in a coupling jar containing electrophoresis buffer $(\mathrm{NaOH}$, TE buffer) for 20 mins and then electrophoresed at a constant current of $300 \mathrm{~mA}$, for $35 \mathrm{mins}$. After electrophoresis, the slides were neutralized using Tris$\mathrm{HCl}$ buffer through three washes (5 mins/each wash) at $\mathrm{pH}$ 7.5, followed by cold ethyl alcohol for $10 \mathrm{mins}$, and then left to dry overnight. The slides were stained by using $80 \mu \mathrm{L}$ ethidium bromide $(20 \mu \mathrm{g} / \mathrm{mL})$ for 20 mins. Then, slides were covered and viewed under an epifluorescence microscope (Zeiss epifluoresent) with an attached CCD camera. Images were saved as electronic files and, for each sample, 50 isolated comets were randomly selected and measured for comet tail length, \%DNA in tail, and tail moment using COMETSCORE software based on the definition by Olive and Banánth [26].

2.5.4. Statistical Data Analysis. Data were expressed as the mean \pm standard error $(\mathrm{M} \pm \mathrm{SE})$. Statistical significances of differences between two groups were determined using Student's $t$-test. The post hoc Tukey HSD test was performed to determine which pairs of different sampling time groups are significantly different from each other. The difference 


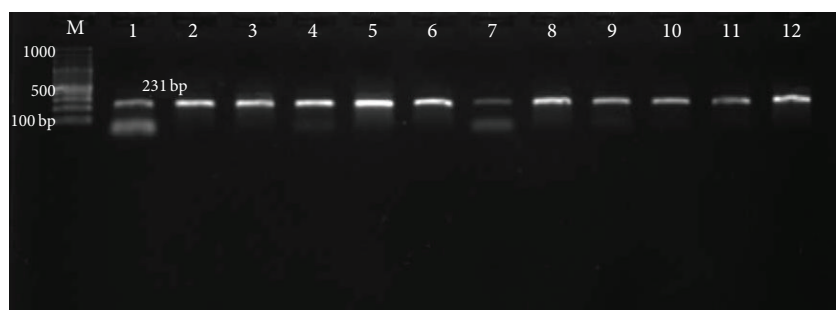

FIgURE 2: A 1.5\% agarose gel separating PCR product for PSEN1 exon 5 (231 bp). Each lane represents an individual animal, in which lane $\mathrm{M}$ is low molecular weight DNA marker (100-1500 bp); lanes 1-3, PCR product for negative control group; lanes 4-6; lanes 7-9 and lanes $10-12$, PCR products for $24 \mathrm{~h}$; 7 -day and 14-day groups, respectively.

between means at the level of $p<0.05$ was considered as significance. Statistics were carried out using statistical analysis systems (SAS) program.

\section{Results}

Results of $\mathrm{TiO}_{2}$ nanoparticles characterization published in previous studies [17] confirmed the rutile-anatase commercial form of nano- $\mathrm{TiO}_{2}$ using XRD analysis and evidenced the nanosize of nano- $\mathrm{TiO}_{2}$ suspension in water using TEM $(46.23 \pm 3.45 \mathrm{~nm})$. Moreover, TEM confirmed the polyhedral morphology of the crystallite structure with increasing surface area and activity.

Figure 1 shows brain sections of different groups, in which (a) represents negative control group; it shows apparently healthy brain cells. $\mathrm{TiO}_{2} \mathrm{NPs}(500 \mathrm{mg} / \mathrm{kg})$ treated group sacrificed after $24 \mathrm{~h}$ shows spongiosis as an extracellular brain edema (blue arrows), together with intracellular brain edema (black arrow) as shown in Figure 1(b). Moreover, $\mathrm{TiO}_{2} \mathrm{NPs}$ $(500 \mathrm{mg} / \mathrm{kg})$ treated group at 7-day sampling time shows an extracellular edema (arrows) (Figure $1(\mathrm{c})$ ), while $\mathrm{TiO}_{2} \mathrm{NPs}$ $(500 \mathrm{mg} / \mathrm{kg})$ treated group at 14-day sampling time shows the most damaged brain tissue, represented by vacuolation of nerve cells with peripheral nucleolus and formation of signet ring appearance (Figure 1(d), arrows).

Figure 2 represents successful PCR product for negative control and different treated groups at expected molecular weight $231 \mathrm{bp}$. Primers were specified for PSEN1 gene exon 5 of mouse.

Figure 3 represents PCR-SSCP for negative control and $\mathrm{TiO}_{2} \mathrm{NPs}$ treated groups at different sampling time, in which, from each $\mathrm{TiO}_{2} \mathrm{NPs}(500 \mathrm{mg} / \mathrm{kg})$ treated group at 7-day and 14-day sampling time, there is one mouse (from three/group) that shows a somatic mutation represented by a band shift in comparison with the negative control group. In another word, one-third of each group has point mutation. While, there is not any difference in the PCR-SSCP pattern of the other treated groups relative to the negative control group. Mutated PCR samples were subjected to direct sequencing to detect point mutation. Direct sequencing shows a point mutation at site $33042 \mathrm{bp}$, at this site $\mathrm{T}$ base was substituted with $\mathrm{G}$ base at the same site in all mutated samples in comparison with negative control group (Figure 4). Therefore, this site has

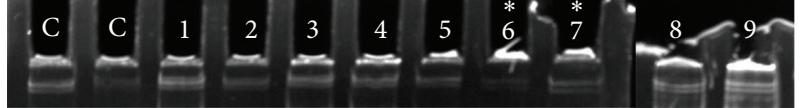

FIGURE 3: A 9\% polyacrylamide gel showing PCR-SSCP for PSEN1 exon 5. Each lane represents an individual animal, in which lane $\mathrm{C}$ represents negative control group; lanes 1-3; lanes 4-6 and lanes 79 represent PCR-SSCP pattern for $24 \mathrm{~h}$; 7-day and 14-day groups, respectively. $(*)$ symbol referred to mutated samples that are found at lanes 6 and 7 in comparison with the negative control group.

a common point mutation in $\mathrm{TiO}_{2} \mathrm{NPs}(500 \mathrm{mg} / \mathrm{kg})$ treated groups at sampling time of 7 days or 14 days.

The genotoxic effect of $\mathrm{TiO}_{2} \mathrm{NPs}$ at different sampling time was evaluated by using Comet assay. Figure 5(a) shows typical nuclei of undamaged cells for negative control group, while Figure 5(b) is a representative photomicrograph for various degrees of DNA damage observed as comets that were seen in all different treated groups. Fifty isolated comets were randomly selected for all groups and measured for comet tail length, \%DNA in tail, and tail moment using COMETSCORE software. The selected data (mean $\pm \mathrm{SE}$ ) for all treated groups were compared using Student's $t$-test (significant difference $p \leq 0.05)$. The results show a significant increase in tail length and tail moment for all treated groups in comparison with the negative control group. Except for \%DNA in tail, it shows a nonsignificant increase only in 14 days' group, while the other groups show a nonsignificant decrease as shown in Figure 6.

Moreover, Figure 6 shows a significant increase in tail length and tail moment when treated groups were statistically compared with $24 \mathrm{~h}$ group, except for tail moment of 7 days' group, while there is a nonsignificant increase in \%DNA in tail of treated groups in comparison with $24 \mathrm{~h}$ group. In addition, Figure 6 statistically compared 14 days' group with 7 days' group; the results show an increase in tail length, \%DNA in tail, and tail moment of 14 days' group; this increase is significant for tail length and tail moment. Table 1 shows that there is a significant difference between groups $24 \mathrm{hr}$ versus 14 days and 7 days versus 14 days at tail length and tail moment.

\section{Discussion}

The present study reports the genotoxic and mutagenic effect of $\mathrm{TiO}_{2} \mathrm{NPs}$ on brain cells at different sampling time. Moreover, exposure to $\mathrm{TiO}_{2} \mathrm{NPs}$ produces mild to moderate change in the cytoarchitecture of brain tissue. We hypothesized that those different toxic and mutagenic effects might lead to $\mathrm{AD}$ incidence.

The present study referred to the most important organ, the brain that might be affected by $\mathrm{TiO}_{2} \mathrm{NPs}$ administration. There are few studies in this point of interest [27]. $\mathrm{TiO}_{2} \mathrm{NPs}$ $(500 \mathrm{mg} / \mathrm{kg})$ treatment at different sampling time leads to brain tissue damage that is highly affected at 14 days' sampling time. Those results were in agreement with Block et al. [28], who reported the in vitro neurotoxicity of $\mathrm{TiO}_{2} \mathrm{NPs}(5 \mathrm{ppm})$, in which it stimulates BV2 microglia to produce ROS that in turn damages neurons in cultures of brain striatum. In addition, Ma et al. [29] reported the neurotoxic effect of 
TABLE 1: Post hoc Tukey HSD test showing the difference between different group pairs.

\begin{tabular}{lcccccc}
\hline Groups & $\begin{array}{c}\text { Tail length } \\
\text { mean } \pm \text { SD }\end{array}$ & $\begin{array}{c}\text { Post hoc Tukey HSD } \\
p \text { value }\end{array}$ & $\begin{array}{c}\text { \% DNA in tail } \\
\text { mean } \pm \text { SD }\end{array}$ & $\begin{array}{c}\text { Post hoc Tukey HSD } \\
p \text { value }\end{array}$ & $\begin{array}{c}\text { Tail moment } \\
\text { mean } \pm \text { SD }\end{array}$ & $\begin{array}{c}\text { Post hoc Tukey HSD } \\
p \text { value }\end{array}$ \\
\hline $24 \mathrm{hr}$ & $15.62 \pm 1.94$ & 0.109 & $20.76 \pm 2.99$ & 0.900 & $3.60 \pm 0.80$ & 0.422 \\
7 days & $20.34 \pm 2.69$ & $0.001^{*}$ & $20.76 \pm 2.99$ & $0.85 \pm 1.05$ & $0.005^{*}$ \\
\hline $24 \mathrm{hr}$ & $15.62 \pm 1.94$ & & $25.01 \pm 4.01$ & & $3.60 \pm 0.80$ & \\
14 days & $31.97 \pm 2.40$ & $0.002^{*}$ & $21.44 \pm 2.69$ & 0.431 & $4.85 \pm 1.05$ & $0.023^{*}$ \\
\hline 7 days & $20.34 \pm 2.69$ & $25.01 \pm 4.01$ & & $8.30 \pm 1.45$ & \\
14 days & $31.97 \pm 2.40$ & & & & & 0.69 \\
\hline
\end{tabular}

${ }^{*}$ Significant difference $(p \leq 0.05)$ using post hoc Tukey HSD test.

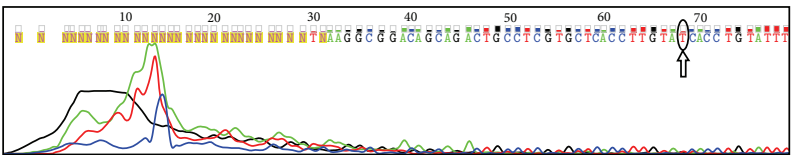

(a)

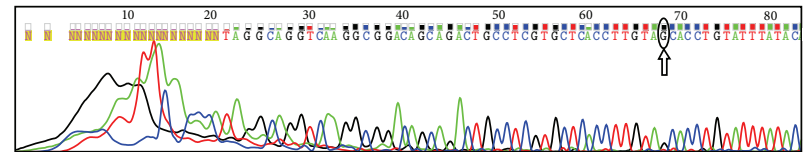

(b)

FIGURE 4: DNA sequence chromatogram of (a) negative control, (b) representative $\mathrm{TiO}_{2} \mathrm{NPs}_{7}$-day and 14-day mutated groups, using PSEN1 exon 5 reverse primer, in which point of mutation is circled and indicated by arrow.

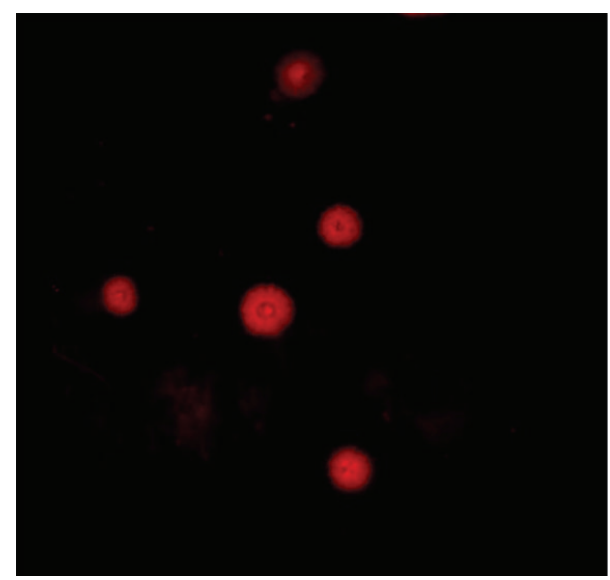

(a)

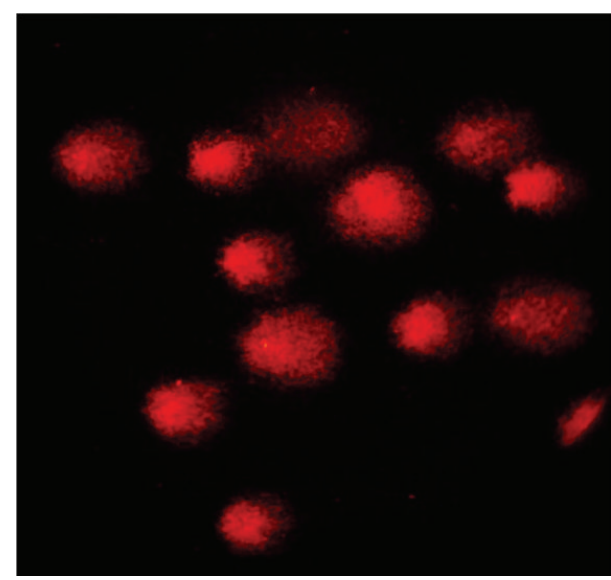

(b)

FIGURE 5: Representative photomicrograph showing (a) typical nuclei of undamaged cells of negative control group and (b) various degrees of DNA damage observed as comets that were seen in all different treated groups.

intra-abdominal injections of $5-150 \mathrm{mg} / \mathrm{kg}$ nano- $\mathrm{TiO}_{2}(5 \mathrm{~nm})$ daily for 14 days in female mice, represented by filamentousshaped neurons and inflammatory cells. Moreover, Li et al. [13] recorded the neurotoxic intratracheal effect of $3.3 \mathrm{mg} / \mathrm{kg}$ nano- $\mathrm{TiO}_{2}(3 \mathrm{~nm})$ once a wk for $4 \mathrm{wks}$ in male mice, represented by exudates, inflammatory infiltration, and necrosis of brain tissue.

The SSCP-pattern followed by direct sequencing revealed the mutagenic effect of $\mathrm{TiO}_{2} \mathrm{NPs}$ at 7 and 14 days' sampling time on PSEN1 gene at exon 5. To the best of our knowledge, this is the first time to detect this point mutation as a result of $\mathrm{TiO}_{2} \mathrm{NPs}$ treatment on this important $\mathrm{AD}$ related gene. Previous study reports the gastric mutagenic effect of $\mathrm{TiO}_{2} \mathrm{NPs}$ (at different doses 5, 50, and $500 \mathrm{mg} / \mathrm{kg} \mathrm{b.w}$ ) treatment, in which it induced high mutation frequencies in p53 exons (5-8) in a dose and time dependent manner
[17]. PSEN gene is assumed to be the catalytic subunit of $\gamma$-secretase, and mutations in the PSEN1 and PSEN2 genes are the most common cause of familial AD [30]. Crews and Masliah [31] referred to previous studies that, in familial forms of $\mathrm{AD}, \mathrm{PSEN}$ mutations result in an increase of amyloid- $\beta(\mathrm{A} \beta)$ protein production or aggregation that in turn results in plaque formation and synaptotoxicity. This might confirm our hypothesis that $\mathrm{TiO}_{2} \mathrm{NPs}_{\text {exposure might }}$ lead to familial form of AD but further studies will be needed in this point to know if this point mutation will be effective or not.

From the present Comet assay, results report the genotoxic potential of $\mathrm{TiO}_{2} \mathrm{NPs}$ on brain cells. Those results were in agreement with Landsiedel et al. [8]; they published a review that describes various knowledge about genotoxicity investigations on nanomaterials including $\mathrm{TiO}_{2} \mathrm{NPs}$. They 


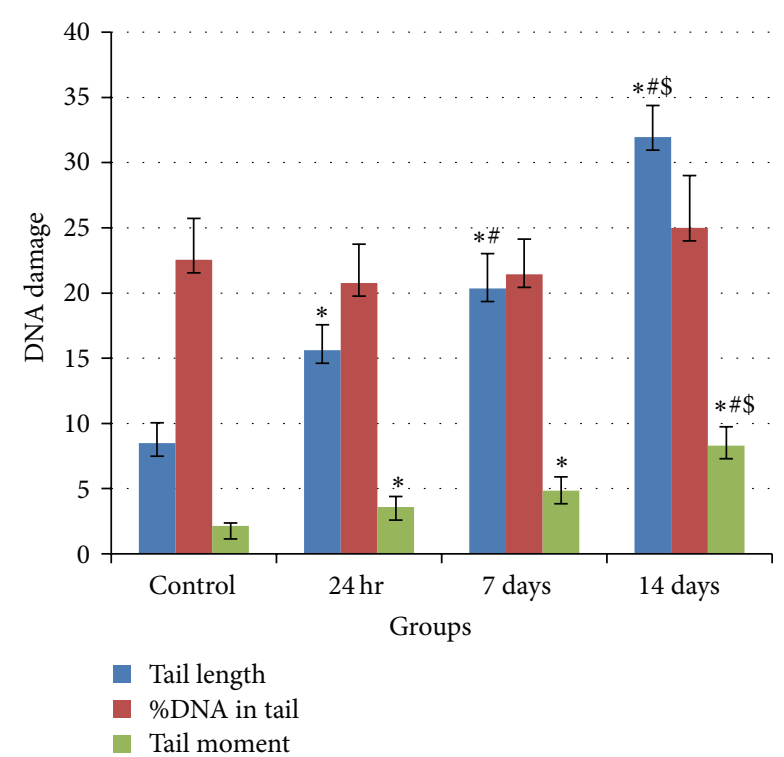

Figure 6: Effect of $\mathrm{TiO}_{2}$ NPs on the DNA (DNA damage was represented by Comet assay) in mice brain cells. Significant difference $(p<0.05)$ using Student's $t$-test, in which ${ }^{*}$ Statistically compared with negative control group; " Statistically compared with 24 h group;

\$Statistically compared with 7-day group.

declare the evidence of $\mathrm{TiO}_{2} \mathrm{NPs}$ genotoxicity represented by micronuclei development, as an indicative of chromosomal damage and DNA damage. Comet assay and the detection of in vitro mammalian chromosomal aberrations are the most commonly used test systems to assess genotoxicity.

Although $\mathrm{TiO}_{2} \mathrm{NPs}$ have the efficiency to stimulate microglia [28], this may lead to oxidative burst that can be represented by the immediate production and release of superoxide anions $\left(\mathrm{O}_{2}^{-\bullet}\right)$ that convert to multiple ROS such as hydrogen peroxide $\left(\mathrm{H}_{2} \mathrm{O}_{2}\right)$, hydroxyl radicals, and peroxynitrites. The excess anions can diffuse from the microglial plasma membrane and damage the proteins, lipids, and DNA of neighboring cells, especially neurons, and might lead to neurodegeneration. Therefore, $\mathrm{TiO}_{2} \mathrm{NPs}$ exposure might lead to the incidence of the most common neurodegenerative disorder, Alzheimer's Disease.

\section{Abbreviations}

$\mathrm{TiO}_{2}$ NPs: Titanium dioxide nanoparticles

AD: $\quad$ Alzheimer's disease

OS: $\quad$ Oxidative stress

PSEN1: Presenilin 1.

\section{Conflict of Interests}

The authors declare that there is no conflict of interests regarding the publication of this paper.

\section{References}

[1] V. Murashov, "Occupational exposure to nanomedical applications," Wiley Interdisciplinary Reviews: Nanomedicine and Nanobiotechnology, vol. 1, no. 2, pp. 203-213, 2009.
[2] P. A. Schulte, M. K. Schubauer-Berigan, C. Mayweather, C. L. Geraci, R. Zumwalde, and J. L. McKernan, "Issues in the development of epidemiologic studies of workers exposed to engineered nanoparticles," Journal of Occupational and Environmental Medicine, vol. 51, no. 3, pp. 323-335, 2009.

[3] M. Ayoub, N. Ahmed, N. Kalaji et al., "Study of the effect of formulation parameters/variables to control the nanoencapsulation of hydrophilic drug via double emulsion technique," Journal of Biomedical Nanotechnology, vol. 7, no. 2, pp. 255-262, 2011.

[4] A. Menard, D. Drobne, and A. Jemec, "Ecotoxicity of nanosized $\mathrm{TiO}_{2}$. Review of in vivo data," Environmental Pollution, vol. 159, no. 3, pp. 677-684, 2011.

[5] K. S. Hougaard, P. Jackson, K. A. Jensen et al., "Effects of prenatal exposure to surface-coated nanosized titanium dioxide (UVTitan). A study in mice," Particle and Fibre Toxicology, vol. 7, article 16, 2010.

[6] A. Weir, P. Westerhoff, L. Fabricius, K. Hristovski, and N. von Goetz, "Titanium dioxide nanoparticles in food and personal care products," Environmental Science and Technology, vol. 46, no. 4, pp. 2242-2250, 2012.

[7] J. Zhao and V. Castranova, "Toxicology of nanomaterials used in nanomedicine," Journal of Toxicology and Environmental Health, Part B: Critical Reviews, vol. 14, no. 8, pp. 593-632, 2011.

[8] R. Landsiedel, M. D. Kapp, M. Schulz, K. Wiench, and F. Oesch, "Genotoxicity investigations on nanomaterials: methods, preparation and characterization of test material, potential artifacts and limitations-many questions, some answers," Mutation Research/Reviews in Mutation Research, vol. 681, no. 2-3, pp. 241-258, 2009.

[9] S. Takenaka, E. Karg, C. Roth et al., "Pulmonary and systemic distribution of inhaled ultrafine silver particles in rats," Environmental Health Perspectives, vol. 109, supplement 4, pp. 547-551, 2001.

[10] W. G. Kreyling, M. Semmler, F. Erbe et al., "Translocation of ultrafine insoluble iridium particles from lung epithelium to extrapulmonary organs is size dependent but very low," Journal of Toxicology and Environmental Health, Part A: Current Issues, vol. 65, no. 20, pp. 1513-1530, 2002.

[11] G. Oberdorster, J. Ferin, and B. E. Lehnert, "Correlation between particle size, in vivo particle persistence, and lung injury," Environmental Health Perspectives, vol. 102, supplement 5, pp. 173-179, 1994.

[12] T. M. Sager, C. Kommineni, and V. Castranova, "Pulmonary response to intratracheal instillation of ultrafine versus fine titanium dioxide: role of particle surface area," Particle and Fibre Toxicology, vol. 5, article 17, 2008.

[13] Y. Li, J. Li, J. Yin et al., "Systematic influence induced by $3 \mathrm{~nm}$ titanium dioxide following intratracheal instillation of mice," Journal of Nanoscience and Nanotechnology, vol. 10, no. 12, pp. 8544-8549, 2010.

[14] P. R. Lockman, J. M. Koziara, R. J. Mumper, and D. D. Allen, "Nanoparticle surface charges alter blood-brain barrier integrity and permeability," Journal of Drug Targeting, vol. 12, no. 9-10, pp. 635-641, 2004.

[15] G. Oberdörster, Z. Sharp, V. Atudorei et al., "Translocation of inhaled ultrafine particles to the brain," Inhalation Toxicology, vol. 16, no. 6-7, pp. 437-445, 2004.

[16] D. J. Selkoe, "Alzheimer's disease: genes, proteins, and therapy," Physiological Reviews, vol. 81, no. 2, pp. 741-766, 2001. 
[17] H. R. H. Mohamed, "Estimation of $\mathrm{TiO}_{2}$ nanoparticleinduced genotoxicity persistence and possible chronic gastritisinduction in mice," Food and Chemical Toxicology, vol. 83, pp. 76-83, 2015.

[18] B. Trouiller, R. Reliene, A. Westbrook, P. Solaimani, and R. H. Schiestl, "Titanium dioxide nanoparticles induce DNA damage and genetic instability in vivo in mice," Cancer Research, vol. 69, no. 22, pp. 8784-8789, 2009.

[19] H. M. Carleton, Carleton's Histological Technique, Oxford University Press, Oxford, UK, 4th edition, 1967.

[20] V. Gautheron, A. Auffret, M. P. Mattson, J. Mariani, and B. Vernet-der Garabedian, "A new and simple approach for genotyping Alzheimer's disease presenilin-1 mutant knock-in mice," Journal of Neuroscience Methods, vol. 181, no. 2, pp. 235240, 2009.

[21] J. Sambrook, E. F. Fritsch, and T. Maniatis, in Molecular Cloning: A Laboratory Manual, J. Sambrook, EF. Fritsch, and T. Maniatis, Eds., CSH Cold Spring Harbor Press, New York, NY, USA, 2nd edition, 1989.

[22] J. Dai, H. Wei, and Y. Xiao, "PCR-RFLP analysis on mitochondrial DNA D-Loop area of six inbred mice," Journal of Medical Colleges of PLA, vol. 21, pp. 709-711, 1999.

[23] J.-G. Dai, J.-X. Min, Y.-B. Xiao, X. Lei, W.-H. Shen, and H. Wei, "The absence of mitochondrial DNA diversity among common laboratory inbred mouse strains," Journal of Experimental Biology, vol. 208, part 23, pp. 4445-4450, 2005.

[24] K. Morimura, S. Yamamoto, T. Murai et al., "LOH and mutational analysis of p53 alleles in mouse urinary bladder carcinomas induced by N-butyl-N-(4-hydroxybutyl) nitrosamine," Carcinogenesis, vol. 20, no. 4, pp. 715-718, 1999.

[25] N. P. Singh, M. T. McCoy, R. R. Tice, and E. L. Schneider, "A simple technique for quantitation of low levels of DNA damage in individual cells," Experimental Cell Research, vol. 175, no. 1, pp. 184-191, 1988.

[26] P. L. Olive and J. P. Banánth, "Induction and rejoining of radiation-induced DNA single-strand breaks: 'tail moment' as a function of position in the cell cycle," Mutation Research-DNA Repair, vol. 294, no. 3, pp. 275-283, 1993.

[27] X. Chang, Y. Zhang, M. Tang, and B. Wang, "Health effects of exposure to nano- $\mathrm{TiO}_{2}$ : a meta-analysis of experimental studies," Nanoscale Research Letters, vol. 8, no. 1, article 51, 10 pages, 2013.

[28] M. L. Block, L. Zecca, and J.-S. Hong, "Microglia-mediated neurotoxicity: uncovering the molecular mechanisms," Nature Reviews Neuroscience, vol. 8, no. 1, pp. 57-69, 2007.

[29] L. Ma, J. Liu, N. Li et al., "Oxidative stress in the brain of mice caused by translocated nanoparticulate $\mathrm{TiO}_{2}$ delivered to the abdominal cavity," Biomaterials, vol. 31, no. 1, pp. 99-105, 2010.

[30] R. J. Kelleher and J. Shen, " $\gamma$-Secretase and human disease," Science, vol. 330, no. 6007, pp. 1055-1056, 2010.

[31] L. Crews and E. Masliah, "Molecular mechanisms of neurodegeneration in Alzheimer's disease," Human Molecular Genetics, vol. 19, no. 1, pp. R12-R20, 2010. 

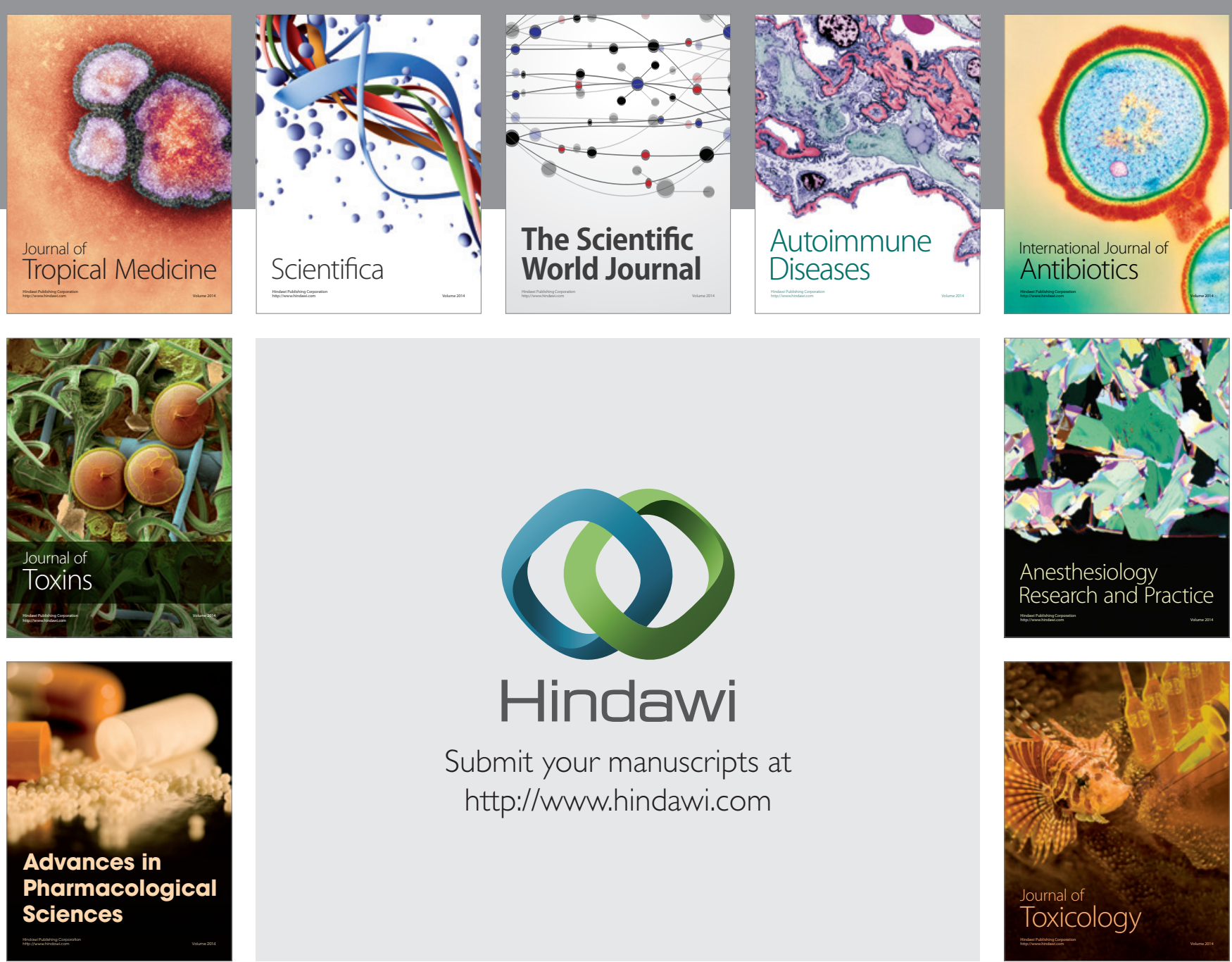

\section{Hindawi}

Submit your manuscripts at

http://www.hindawi.com
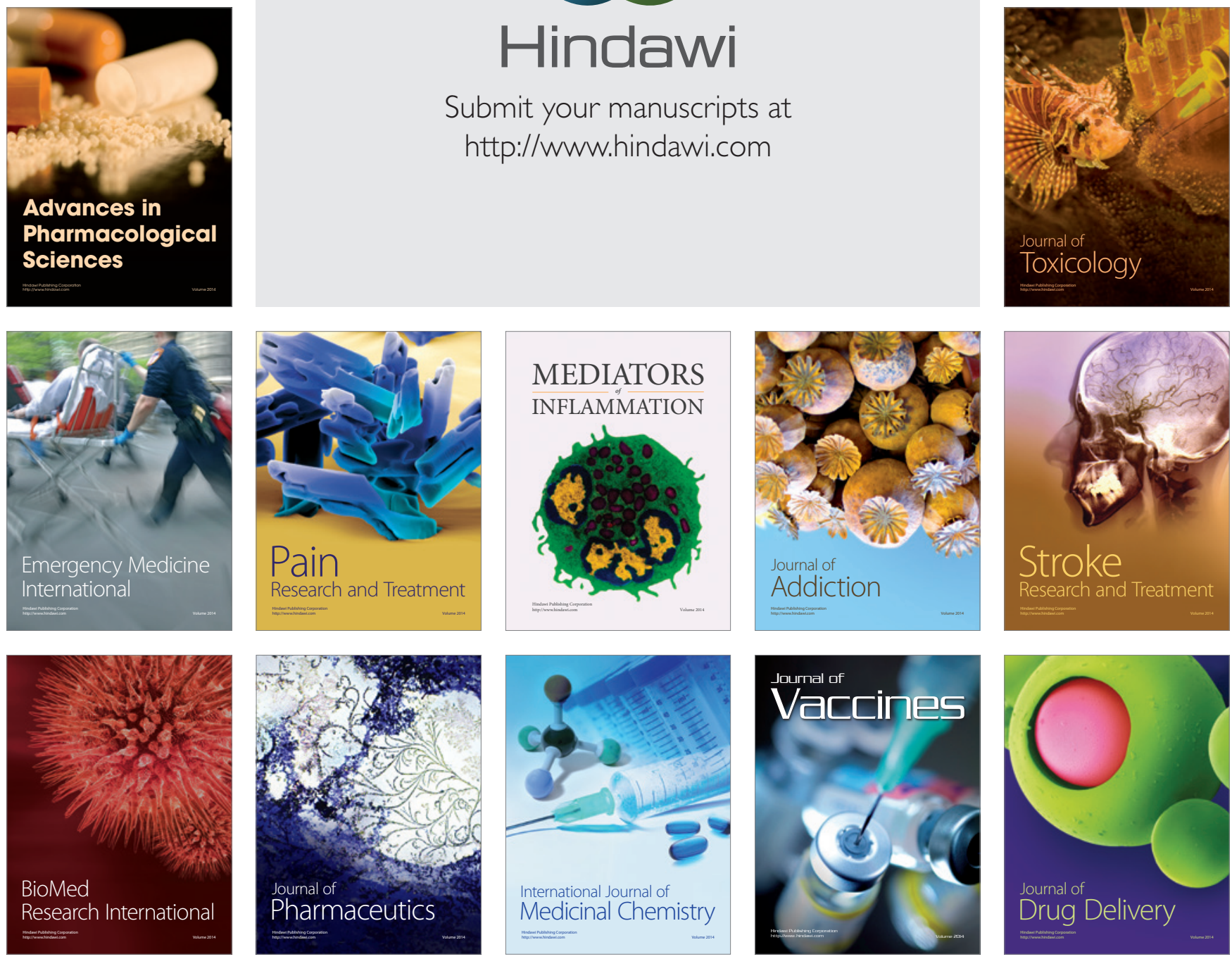